Article

\title{
Molecular and Isotopic Composition of Hydrate-Bound, Dissolved and Free Gases in the Amazon Deep-Sea Fan and Slope Sediments, Brazil
}

\author{
Luiz F. Rodrigues ${ }^{1, *}$, João M. Ketzer ${ }^{2}{ }^{(}$, Rafael R. Oliveira ${ }^{3}$, Victor H.J.M. dos Santos ${ }^{1}{ }^{(\mathbb{D}}$, \\ Adolpho H. Augustin ${ }^{1}{ }^{1}$, Jose A. Cupertino ${ }^{1}$, Adriano R. Viana ${ }^{4} \mathbb{D}^{\circ}$, Bruno Leonel ${ }^{5}$ \\ and Wilhelm Dorle ${ }^{5}$ \\ 1 Institute of Petroleum and Natural Resources, PUCRS-Pontifícia Universidade Católica do Rio Grande do \\ Sul, Porto Alegre 90619-900, Brazil; victor.santos@pucrs.br (V.H.J.M.d.S.); \\ adolpho.augustin@pucrs.br (A.H.A.); jose.cupertino@pucrs.br (J.A.C.) \\ 2 Department of Biology and Environmental Science, Linnaeus University, 391-82 Kalmar, Sweden; \\ marcelo.ketzer@Inu.se \\ 3 Neoprospecta, Florianópolis 88056-000, Brazil; rafael.oliveira@neoprospecta.com \\ 4 PETROBRAS-E\&P EXPLORATION, Rio de Janeiro 20031-170, Brazil; aviana@petrobras.com.br \\ 5 Seaseep Dados de Petróleo, Rio de Janeiro 20031-144, Brazil; bleonel@seaseep.com.br (B.L.); \\ wdorle@seaseep.com.br (W.D.) \\ * Correspondence: frederico.rodrigues@pucrs.br; Tel.: +55-(51)-3320-3689
}

Received: 21 December 2018; Accepted: 22 January 2019; Published: 31 January 2019

\begin{abstract}
In this work, we investigated the molecular stable isotope compositions of hydrate-bound and dissolved gases in sediments of the Amazon deep-sea fan and adjacent continental slope, Foz do Amazonas Basin, Brazil. Some cores were obtained in places with active gas venting on the seafloor and, in one of the locations, the venting gas is probably associated with the dissociation of hydrates near the edge of their stability zone. Results of the methane stable isotopes $\left(\delta^{13} \mathrm{C}\right.$ and $\delta \mathrm{D})$ of hydrate-bound and dissolved gases in sediments for the Amazon fan indicated the dominant microbial origin of methane via carbon dioxide reduction, in which ${ }^{13} \mathrm{C}$ and deuterium isotopes were highly depleted $\left(\delta^{13} \mathrm{C}\right.$ and $\delta \mathrm{D}$ of $-102.2 \%$ to $-74.2 \% \mathrm{~V}-\mathrm{PDB}$ and -190 to $-150 \% \mathrm{~V}-\mathrm{SMOW}$, respectively). The combination of $\mathrm{C} 1 /(\mathrm{C} 2+\mathrm{C} 3)$ versus $\delta^{13} \mathrm{C}$ plot also suggested a biogenic origin for methane in all analysed samples (commonly $>1000$ ). However, a mixture of thermogenic and microbial gases was suggested for the hydrate-bound and dissolved gases in the continental slope adjacent to the Amazon fan, in which the combination of chemical and isotopic gas compositions in the $\mathrm{C} 1 /(\mathrm{C} 2+\mathrm{C} 3)$ versus $\delta^{13} \mathrm{C}$ plot were $<100$ in one of the recovered cores. Moreover, the $\delta^{13} \mathrm{C}$-ethane of $-30.0 \%$ indicates a thermogenic origin.
\end{abstract}

Keywords: Amazon fan; gas hydrate; thermogenic gas; biogenic gas; molecular composition; isotopic composition

\section{Introduction}

Energy production is one of the most important topics in our society nowadays owing to the increasing pressure on conventional sources based on petroleum. Global efforts encourage scientific programs to identify new alternative, cleaner, and unconventional energy sources [1]. One such alternative is gas hydrates, which are crystalline, ice-like structures that contain guest molecules, mainly methane [2]. Gas hydrates are widely distributed around the world and can be found in permafrost and submarine environments that present specific conditions of pressure and temperature for their formation [2-5]. Among the potential $\mathrm{CH}_{4}$ sources, gas hydrates stand out as an important 
unconventional energy reserve, with quantities comparable to other known conventional sources [3-7]. The hydrocarbons trapped in hydrates can be derived from biological methanogenesis (biogenic origin) or formed by the thermal decomposition of organic matter (thermogenic origin) $[4,8]$.

Besides being an important energy source, methane is an important player in the global biogeochemical carbon cycle and accounts for $20 \%$ of greenhouse effects [9-11]. In a global warming scenario, the large amount of methane may represent an environmental hazard, since destabilization of gas hydrates could result in a high volume of gas releasing into the atmosphere, potentially promoting catastrophic geological consequences $[6,7,12]$. Thus, the mapping of gas hydrate distribution, inventory assessment, and a comprehensive understanding of their role in energy and environmental issues should justify the establishment of a global agenda on this issue.

In Brazil, the Rio Grande Cone Gas Hydrate Province in the Pelotas Basin [13] is one of the main areas with gas hydrate deposits with associated chemosynthetic communities [14,15], and consists of the first discovery of gas hydrates in the western South Atlantic. The direct recovery of gas hydrate was performed through sediment sampling by piston coring and the results showed that the gas was mainly composed of methane of biogenic origin [13]. Recently, other works described the methane-sulphate interface dynamics [16] and the origin of organic matter in hydrate-bearing sediments [17] in the Pelotas Basin region.

The Ocean Drilling Program (ODP) 155 LEG, was performed in the Amazon fan area and resulted in a drilling campaign with 17 sites and covered an extensive area of the mid- and lower fan [18-20] The geochemical modelling conducted on the Amazon fan sediment concluded that the region is very susceptible to the production of biogenic methane. This $\mathrm{CH}_{4}$ could be accumulated along the sediment column and, in regions with adequate pressure and temperature (waters deeper than $600 \mathrm{~m}$ ), is likely to be trapped in gas hydrates [1]. The mass of organic carbon trapped in the Amazon deep-sea fan sediments is, for comparison, larger than the mass of carbon stored at the present-day Amazon forest [21]. In a previous work, from the seismic record of the Amazon fan, the presence of gas charged sediments was found [22].

From the ODP Leg 155 records and seismic investigations, a slope failure was detected that was associated with a massive sediment mass-transport deposits along the fan structure [18,23-25]. These catastrophic events were associated with glacial-interglacial cycles, which result in sea level (and pressure and bottom water temperature) changes and the destabilization of the gas hydrate layer. The subsequent gas release increased pore pressure and destabilization of the sediment package and resulted in the triggering of mass transport of deposits [23,24].

Another strong indicator of the existence of gas hydrates in the Amazon region is the presence of bottom simulating reflectors, observed within the upper fan [18,23-28]. These seismic records were described in water depths of about $2000 \mathrm{~m}$, and are within the gas hydrate stability zone (GHSZ) [27]. The presence of gas hydrates together with gas venting sites at the seafloor in the Amazon deep-sea fan and Foz do Amazonas Basin was confirmed by the recovery of samples during a sea campaign in 2015. The gas compositions from hydrates recovered in vents indicate essentially biogenic sources with a possible thermogenic contribution, dominantly methane $813 \mathrm{C}$ from $-81.1 \%$ to $-59.2 \%$ [21].

In the present work, additional chemistry tests were performed to improve the discussion of the origin of gas composition and isotopic analysis obtained through piston core sampling between hydrate-bound and dissolved gases in sediments collected in the Amazon fan and continental slope of the Foz do Amazonas Basin, Brazil. The gas composition results presented in this study indicate that the Amazon fan area represents a promising new energy frontier. The knowledge of the composition and origin of the hydrate-bound, dissolved and free gases in the Amazon deep-sea fan and slope sediments will help with assessing the potential of methane hydrates as an energy source and their relationship with the global carbon cycle and climate. 


\section{Study Area and Geological Setting}

The Amazon fan is a deep-sea structure located in the Foz do Amazonas Basin, and extends seawards from the continental shelf, from the shelf break in front of the Amazon River to the Demerara Abyssal Plain (Figure 1). Sediments deposited in the fan were sourced mostly from the Andean belt [29] since the Late Miocene [18] and carried to the Atlantic Ocean and the Foz do Amazonas Basin by the Amazon River, which has one of the largest sediment [26] and organic matter [30] discharges in the world. In addition to the Amazon fan, we also included in this work data from the adjacent continental slope to the northwest. This area is formed by a series of submarine canyons, approximately $35 \mathrm{~km}$ wide and $130 \mathrm{~km}$ long, in which each canyon is formed by dozens of small submarine channels connected to a main canyon (Figure 1). These structures begin at the shelf break and develop down to the upper continental slope at water depths of more than $3000 \mathrm{~m}$. Information about geological models and the hydrates' stability zone for the study area can be found in a previous manuscript [21] that discusses the new evidence on widespread gas venting from the gas hydrate stability zone on the upper Amazon deep-sea fan.

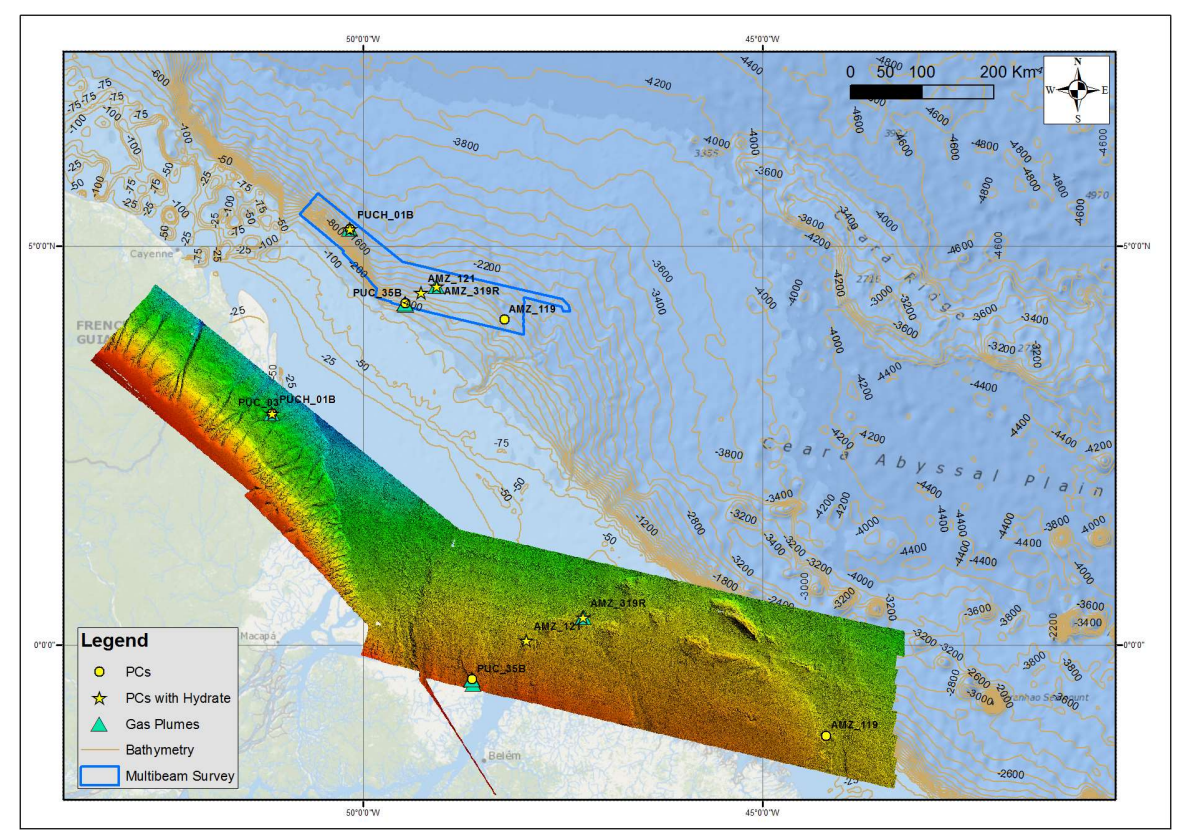

Figure 1. Location map showing the bathymetry (coloured) of the study area in the Amazon deep-sea fan, the adjacent continental slope area to the northwest with small canyons connected to a main canyon channel. The blue dots are the piston cores used in this study.

\section{Samples and Methods}

The samples and data used in this study were collected on board the research vessel Inspector II, equipped with a $6 \mathrm{~m}$ long piston corer unit. The precision of sea floor sampling was assured by an Ultra-short baseline (USBL) transponder/responder (Sonardyne, London, UK) fastened $5 \mathrm{~m}$ above the corer. A total of four oceanographic missions were carried out in July 2012, July 2015, August 2015 and September 2015. The first mission was dedicated to surveying the area with a multi-beam echo sounder (MBES) and covered an area of $18,490 \mathrm{~km}^{2}$, generating high-resolution seafloor maps $(15 \times 15 \mathrm{~m}$ unit bathymetry cell and $10 \times 10 \mathrm{~m}$ unit backscatter cell $)$ and acoustic profiles of the water column. A high-resolution (CHIRP $3.5 \mathrm{kHz}$ ) seismic profile with average penetration of $10 \mathrm{~m}$ below the seafloor was acquired with a sub-bottom profiler, together with the MBES survey. The second, third and fourth missions were dedicated to core sediment sampling at specific targets (possible vent sites such as pockmarks and mounds with high backscatter signatures) on the seafloor, previously identified with the MBES data. Four cores were collected in the Amazon fan proper (cores PUC 35B, 
AMZ 119, AMZ 121 and AMZ 319R), and two cores were collected in the adjacent continental slope area (cores PUC 03 and PUCH 01B). Cores PUC 35B, AMZ 319R, PUC 03 and PUCH 01B, were collected in active gas venting sites in the area [21]. The cores recovered were cut into sections of $1 \mathrm{~m}$ and the sediment samples were collected at the top and base of each core section.

Sediment samples for gas analysis (C1-C5 hydrocarbons) were collected from the top of each section (i.e., every $100 \mathrm{~cm}$ of the core). Samples were collected from the freshly exposed tops of the sections using a spatula and were immediately placed in gas-tight IsoJar containers from Isotech Laboratories Inc., Champaign (IL), EUA. The sediment sample filled one-third of gas-tight recipients (IsoJars), while another third was filled with distilled water, leaving the top third filled with air (headspace). The benzalkonium chloride bactericide were added into the IsoJars in order to eliminate microbial activity and the jars were kept refrigerated at $4{ }^{\circ} \mathrm{C}[31,32]$.

We also collected hydrate samples, in addition to sediment samples. The hydrate samples were collected using a spatula, placed in IsoJar containers and kept at room temperature. The headspace gases formed by the dissociation of hydrates inside the container were sampled and analysed. In this work, we present the carbon dioxide quantification and the respective values of carbon-stable isotope $\left(\delta^{13} \mathrm{C}-\mathrm{CO}_{2}\right)$, the deuterium isotope results of methane $\left(\delta \mathrm{D}-\mathrm{CH}_{4}\right)$ and carbon-stable isotope results of ethane $\left(\delta^{13} \mathrm{C}-\mathrm{C}_{2} \mathrm{H}_{6}\right)$ of three gas hydrate samples taken from three representative piston cores (PUCH 01B, AMZ 319R, and AMZ121). The results of $\delta^{13} \mathrm{C}^{-} \mathrm{CH}_{4}$ and gas composition (C1-C5 hydrocarbons) were previously reported [21].

Gas composition was determined using a gas chromatograph (Shimadzu Corporation, model GC-2014, from Kyoto, Japan) equipped with a VPPlot Alumina/ $\mathrm{KCl}$ capillary column (Sigma-Aldrich Corporation., St. Louis, MO, USA), measuring $30 \mathrm{~m} \times 0.53 \mathrm{~mm}$ with a $10.0 \mu \mathrm{m}$ film. The analytical conditions used in this work are described in previous work [33]. Carbon-stable isotope analyses of the headspace gases were performed using a Thermo Fisher Scientific gas chromatograph (Waltham, MA, USA), coupled to a Thermo Scientific DELTAV Plus isotope ratio monitoring mass spectrometer via a Thermo GC IsoLink and Conflo IV interface (Thermo Fisher Scientific). The gas chromatograph contained a $30 \mathrm{~m} \times 0.32 \mathrm{~mm}$ fused silica column, Carboxen Plot 1006 (Sigma-Aldrich Corporation., St. Louis, MO, EUA), and was operated at a heating ramp of $70-150{ }^{\circ} \mathrm{C}$, over $30 \mathrm{~min}$.

\section{Results and Discussion}

\subsection{Amazon Fan}

The gas composition of free gas from sediment samples collected in cores PUC 35B, AMZ 119, AMZ 121 and AMZ 319R were dominated by methane ( 81.05 to $99.97 \%)$, followed by $\mathrm{CO}_{2}(0.76$ to $12.62 \%$ ) and ethane (0.01 to $0.3 \%)$. Traces of propane were found in AMZ 121(0.007 to $0.013 \%$ ) and AMZ 319R (0.03 to $0.07 \%)$. The $\mathrm{C} 1 /(\mathrm{C} 2+\mathrm{C} 3)$ ratio varied from $330-31,049$ whereas $\delta^{13} \mathrm{CH}_{4}$ and $\delta \mathrm{D}-\mathrm{CH}_{4}$ values ranged from $-102.2 \%$ to $-74.2 \%$ and $-192 \%$ to $-150 \%$, respectively. It was not possible to analyse the carbon isotope compositions of ethane from hydrates, because the ethane concentrations were below the limit of detection of the technique (Table 1).

According to Bernard classification [34], the combination of gas, chemical and isotopic compositions of free gas from sediments in the $\mathrm{C} 1 /(\mathrm{C} 2+\mathrm{C} 3)$ versus $\delta^{13} \mathrm{C}$ plot, suggested a biogenic origin for all analysed samples from the Amazon fan (Figure 2a). Microbial $\mathrm{CO}_{2}$ reduction mainly generates methane, and there are traces of ethane and propane, so the relative $\mathrm{C} 1 / \mathrm{C} 2+$ rations are very high (commonly >1000). Based on the classification scheme of Whiticar [35], $\delta^{13} \mathrm{CH}_{4}$ and $\delta \mathrm{D}-\mathrm{CH}_{4}$ are typically in the range for microbial methane production by $\mathrm{CO}_{2}$ reduction (Figure $2 \mathrm{~b}$ ). This biogenic origin was also reported in other gas hydrate provinces around the world, like Rio Grande Cone [13], Blake Ridge [36], and the Black Sea [37,38].

The gas hydrate collected in PC AMZ 319R (Table 1) was essentially formed by methane (>99\%) with minor quantities of ethane, propane, propylene and low amounts of $\mathrm{CO}_{2}$. The $\mathrm{C} 1 /(\mathrm{C} 2+\mathrm{C} 3)$ ratio for these samples ranges from 2406 to 2299 (Figure 2a), whereas $\delta^{13} \mathrm{C}$ methane values range from 
$-79.5 \%$ to $-77.3 \%$ [21], while for $8 \mathrm{D}-\mathrm{CH}_{4}$, values range from $-188 \%$ to $-186 \%$ (Table 1 ). AMZ 121 was assayed by only one hydrate sample and the gas composition results showed a hydrate formed by methane $(99.88 \%)$ and carbon dioxide $(1.11 \%)$. The $\delta^{13} \mathrm{CH}_{4} / \delta \mathrm{D}-\mathrm{CH}_{4}$ values were $-81.1 \%$ [21] and $-190 \%$, respectively. According to the classification proposed by Bernard et al. [34], (Figure 2a), the samples obtained at the AMZ 319R and AMZ121 sites are consistent with the field of microbial gas and both samples collected would be of microbial origin produced by microbial $\mathrm{CO}_{2}$ reduction (Figure $2 \mathrm{~b}$ ).
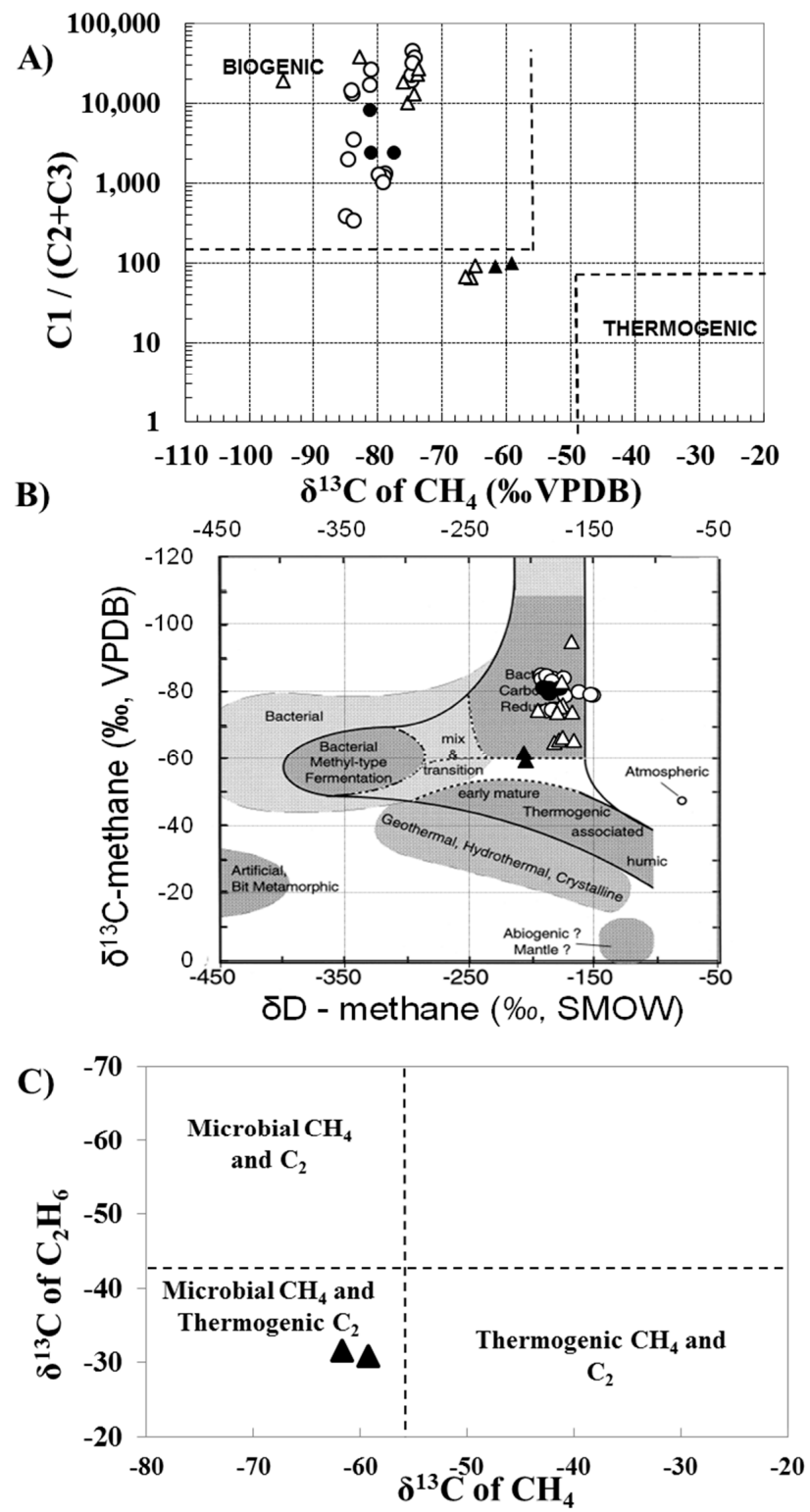

Figure 2. Diagram showing the relationship between molecular and isotopic compositions of hydrate-bound, free and dissolved gases in sediments of the Amazon fan and adjacent continental slope, based on the classifications of Whiticar [35], Milkov [39] and Taylor et al. [40]. (A) Chemical and isotopic compositions of free gas from sediments using $\mathrm{C} 1 /(\mathrm{C} 2+\mathrm{C} 3)$ versus ${ }^{13} \mathrm{C}$ plot; (B) Chemical and isotopic compositions of free gas from sediments using ${ }^{13} \mathrm{C}_{-}-\mathrm{CH}_{4}$ versus $\mathrm{D}-\mathrm{CH}_{4} ;(\mathbf{C})$ Chemical and isotopic compositions of free gas from sediments using ${ }^{13} \mathrm{C}_{2} \mathrm{H}_{6}$ versus ${ }^{13} \mathrm{CH}_{4}$. Open and solid circles indicate hydrate-bound gases, and dissolved and free gases in pore water at the Amazon fan area, respectively, whereas open and solid triangles indicate hydrate-bound, free and dissolved gases in the adjacent continental slope study area northeast of the Amazon fan, respectively. The results of $\delta^{13} \mathrm{C}_{-} \mathrm{CH}_{4}$ and gas composition (C1-C5 hydrocarbons) for gas hydrate were previously reported [21]. 


\subsection{Northwest Continental Slope Area}

Average hydrocarbon compositions in gases from sediment samples of PUC 03 and PUCH 01B were, in general, strongly dominated by methane $(91.06-98.88 \%)$ and $\mathrm{CO}_{2}(0.20-8.94 \%)$. Only in PUCH 01B were ethane $(1.12-1.47 \%)$, propane $(0.005 \%)$, propylene $(0.002-0.017 \%)$ and traces of butane and butene (1.05 and $1.33 \%$, respectively) found.

The $\mathrm{C} 1 /(\mathrm{C} 2+\mathrm{C} 3)$ ratio for PUC 03 and PUCH 01B varied from 847-22,484 and 65.8-92.7, respectively, whereas $\delta^{13} \mathrm{CH}_{4}$ values for PUC 03 and PUCH 01B ranged from $-94.8 \%$ to $-73.7 \%$ and $-66.3 \%$ to $-64.9 \%$, respectively. For $8 \mathrm{D}-\mathrm{CH}_{4}$, the values range from $-194 \%$ to $-167 \%$ and $-181 \%$ to $-166 \%$ for PUC 03 and PUCH 01B, respectively. Regarding the isotope composition of carbon of ethane from hydrates, the values obtained were $-30.8 \%$ and $-31.5 \%$ (Table 1 ).

Figure $2 \mathrm{a}$ shows the relationship between the isotopic ratios and gas compositions of hydrate-bound gas, and free and dissolved gases in sediments. According to the classification proposed by Bernard et al. [34], the analysed methane gas obtained at the PUC 03 site plotted in the field of microbial gas, whereas some samples from the PUCH 01B site suggested a mix between microbial and thermogenic sources (Figure 2a). In the $\delta^{13} \mathrm{C}-\delta \mathrm{D}$ diagram of methane shown in Figure $2 \mathrm{~b}$ and based on the classification of Whiticar [35], $\mathrm{C} 1$ at all sites would be of microbial origin produced by microbial $\mathrm{CO}_{2}$ reduction (Figures 1 and $2 \mathrm{~b}$ ).

The gas hydrate recovered at PUCH 01B revealed a mixture of biogenic and thermogenic gases, both in the chemical and isotopic compositions in the $\mathrm{C} 1 /(\mathrm{C} 2+\mathrm{C} 3)$ versus $\delta^{13} \mathrm{C}$ plot (Figure 2a). Compared with the deep ocean sediment from the Gulf of Mexico, the gas hydrate recovered always contained $>99 \%$ methane. The only exception was the gas hydrate obtained from the ODP Leg 96 with the low $\mathrm{C} 1 /(\mathrm{C} 2+\mathrm{C} 3)$ value of 160 . Gas hydrate samples recovered from the Caspian Sea contained methane at $59.1-96.2 \%$ in the hydrocarbon gas mixtures, with $\mathrm{C} 1 /(\mathrm{C} 2+\mathrm{C} 3)$ values ranging from 1.7 to 45. This gas hydrate of the Caspian Sea was associated with fluid venting from the Buzdag and Elm mud volcanoes [41].

The gas hydrate recovered at PUCH 01B contained $>98 \%$ methane, around $1 \%$ ethane, $0.02 \%$ propylene, and $0.07-0.5 \%$ of $\mathrm{CO}_{2}$, and the $\mathrm{C} 1 /(\mathrm{C} 2+\mathrm{C} 3)$ value ranged between 89 and 98 . Both samples collected would be of microbial origin, produced by microbial $\mathrm{CO}_{2}$ reduction, as shown in Whiticar's diagram. However, Whiticar's diagrams [35] only correspond to results for the isotopic composition of methane. According to the isotopic analysis diagrams of ethane, the origin based on the classification of Milkov [39] is thermogenic. This suggests that a thermogenic gas is possibly present in the Northwest continental slope area, and constitutes a detectable gas constituent of the gas mix, together with methane resulting from microbial $\mathrm{CO}_{2}$ reduction.

It is very important to explain that in some cores we found ethane without the presence of propane or butane (i.e., PUCH01B). Biodegradation of original gas composition can also produce "dry gas" due to the preferential removal of propane and butane [42]. Ethane is rarely or much less easily consumed, so the ethane/propane ratio increases with the biodegradation rate. Because propane amounts are much lower than those of ethane, its depletion does not significantly influence the Bernard ratio. In fact, there are examples of gas from biodegraded reservoirs with very low Bernard ratios, due to high ethane concentrations [42,43].

Light hydrocarbons and gases (C2-C5 hydrocarbons) can also be biodegraded; propane and n-butane are degraded the most rapidly. Biodegradation of $\mathrm{C} 2-\mathrm{C} 5$ hydrocarbons, increases the methane content. This may result in the production of a gas cap enriched in methane following the removal of wet gas components (C2-C5 alkanes), and probably also by direct production of methane during biodegradation [44-47]. However, even with the biodegradation of gas, it was possible to detect the presence of some amounts of other hydrocarbons distributed at different depths in the piston core. Although there were trace amounts of $\mathrm{C} 3-\mathrm{C} 4$, we suggest that the biodegradation process changed the original composition of gas. In addition, it was not possible to detect trace amounts of C3-C4 in some depths, because the concentrations were below the detection limit of the analytical technique. 
Table 1. Molecular and stable isotope compositions of hydrate-bound gases (HG) and headspace gases at all sites. Methane (C1), ethane (C2), propane (C3), propene $(=\mathrm{C} 3)$, butene (=C4), butane (C4), pentane (C5). The depth is in meters below sea floor (mbsf).

\begin{tabular}{|c|c|c|c|c|c|c|c|c|c|c|c|c|c|c|}
\hline $\begin{array}{c}\text { Piston } \\
\text { Core }\end{array}$ & Depth (mbsf) & ${ }^{13} \mathrm{C}-\mathrm{CH}_{4}$ & $\mathrm{D}-\mathrm{CH}_{4}$ & ${ }^{13} \mathrm{C}-\mathrm{C}_{2} \mathrm{H}_{6}$ & ${ }^{13} \mathrm{C}-\mathrm{CO}_{2}$ & $\mathrm{C} 1(\%)$ & C2 (\%) & C3 (\%) & $\begin{array}{c}=\mathrm{C} 3 \\
(\%)\end{array}$ & $\begin{array}{c}=\mathrm{C} 4 \\
(\%)\end{array}$ & C4 (\%) & C5 (\%) & $\mathrm{CO}_{2}(\%)$ & $\mathrm{C} 1 / \mathrm{C}+$ \\
\hline \multirow{7}{*}{ PUC 03} & 0.3 & -76 & -175 & n.d. & -44.5 & 96.12 & n.d. & n.d. & n.d. & n.d. & n.d. & n.d. & 3.88 & 18,336 \\
\hline & 1 & -75.5 & -177 & n.d. & -41.1 & 96.52 & n.d. & n.d. & n.d. & n.d. & n.d. & n.d. & 3.48 & 9955 \\
\hline & 2 & -74.4 & -195 & n.d. & -45.2 & 96.91 & n.d. & n.d. & n.d. & n.d. & n.d. & n.d. & 3.09 & 13,030 \\
\hline & 3 & -73.9 & -167 & n.d. & -43.4 & 97.16 & n.d. & n.d. & n.d. & n.d. & n.d. & n.d. & 2.84 & 22,484 \\
\hline & 4 & -73.7 & -179 & n.d. & -48.6 & 92.19 & n.d. & n.d. & n.d. & n.d. & n.d. & n.d. & 7.81 & 1214 \\
\hline & 5 & -82.8 & -176 & n.d. & -46.2 & 94.22 & n.d. & n.d. & n.d. & n.d. & n.d. & n.d. & 5.78 & 847 \\
\hline & 6 & -94.8 & -168 & n.d. & -49.7 & 91.06 & n.d. & n.d. & n.d. & n.d. & n.d. & n.d. & 8.94 & 18,679 \\
\hline \multirow{6}{*}{ PUCH01B } & $0.3(\mathrm{HG})$ & -59.2 & -205 & -30.8 & -21.4 & 98.88 & 1.12 & n.d. & 0.002 & n.d. & n.d. & n.d. & n.d & 98.1 \\
\hline & $0.3(\mathrm{HG})$ & -61.7 & -206 & -31.5 & -21.8 & 98.75 & 1.23 & n.d. & 0.02 & n.d. & n.d. & n.d. & n.d & 89.2 \\
\hline & 0.7 & -64.9 & -182 & n.d. & -41.2 & 98.54 & 1.42 & n.d. & 0.04 & n.d. & n.d. & n.d. & n.d & 77.1 \\
\hline & 1 & -65.6 & -178 & n.d. & -41.5 & 98.49 & 1.29 & 0.005 & 0.017 & n.d. & n.d. & n.d. & 0.2 & 92.7 \\
\hline & 1.4 & -66.3 & -175 & n.d. & -38.7 & 96.77 & 1.47 & n.d. & n.d. & n.d. & n.d. & n.d. & 1.8 & 65.8 \\
\hline & 1.9 & -65.5 & -166 & n.d. & -45.3 & 94.49 & 1.43 & n.d. & n.d. & 1.33 & 1.05 & n.d. & 1.71 & 24.84 \\
\hline \multirow{3}{*}{ PUC35B } & 0.4 & -81.1 & -181 & n.d. & -52.8 & 90.61 & n.d. & n.d. & n.d. & n.d. & n.d. & n.d. & 9.39 & 16,429 \\
\hline & 1.4 & -83.9 & -183 & n.d. & -49.7 & 91.88 & n.d. & n.d. & n.d. & n.d. & n.d. & n.d. & 8.12 & 13,010 \\
\hline & 2.6 & -84 & -174 & n.d. & -33.9 & 93.31 & n.d. & n.d. & n.d. & n.d. & n.d. & n.d. & 6.69 & 14,039 \\
\hline \multirow{5}{*}{ AMZ119 } & 0.2 & -74.6 & -182 & n.d. & -9.3 & 93 & n.d. & n.d. & n.d. & n.d. & n.d. & n.d. & 7 & 43,905 \\
\hline & 1 & -74.8 & -182 & n.d. & -7.7 & 81.05 & n.d. & n.d. & n.d. & n.d. & n.d. & n.d. & 18.5 & 19,017 \\
\hline & 2.9 & -74.2 & -188 & n.d. & -8.1 & 91.86 & n.d. & n.d. & n.d. & n.d. & n.d. & n.d. & 8.14 & 36,842 \\
\hline & 4 & -74.6 & -179 & n.d. & -10.4 & 87.38 & n.d. & n.d. & n.d. & n.d. & n.d. & n.d. & 12.62 & 22,283 \\
\hline & 5.3 & -74.6 & -183 & n.d. & -10.3 & 91.49 & n.d. & n.d. & n.d. & n.d. & n.d. & n.d. & 8.51 & 31,049 \\
\hline \multirow{6}{*}{ AMZ121 } & 0.6 & -102.2 & -190 & n.d. & -64.7 & 91.35 & 0.244 & n.d. & n.d. & n.d. & n.d. & n.d. & 8.41 & 375 \\
\hline & 1.8 & -84.9 & -192 & n.d. & -35.2 & 94.04 & 0.285 & n.d. & n.d. & n.d. & n.d. & n.d. & 5.68 & 330 \\
\hline & 2.8 & -84.6 & -188 & n.d. & -36.6 & 99.47 & 0.03 & 0.007 & n.d. & n.d. & n.d. & n.d. & 0.49 & 3413 \\
\hline & 3.0 & -83.7 & -192 & n.d. & -33.1 & 97.17 & n.d. & 0.05 & 0.065 & n.d. & n.d. & n.d. & 2.72 & 1974 \\
\hline & 3.2 & -83.7 & -186 & n.d. & -35.1 & 99.65 & 0.02 & 0.005 & n.d. & n.d. & n.d. & n.d. & 0.32 & 5536 \\
\hline & $3.5(\mathrm{HG})$ & -81.1 & -190 & n.d. & -35.0 & 98.88 & 0.01 & n.d. & n.d. & n.d. & n.d. & n.d. & 1.11 & 7936 \\
\hline \multirow{6}{*}{ AMZ319R } & 1.0 & -78.8 & -173 & n.d. & -42.6 & 98.33 & 0.08 & n.d. & n.d. & n.d. & n.d. & n.d. & 1.59 & 1301 \\
\hline & $1.5(\mathrm{HG})$ & -80.9 & -186 & n.d. & -37.2 & 99.36 & 0.04 & n.d. & n.d. & n.d. & n.d. & n.d. & 0.60 & 2406 \\
\hline & 2.4 & -78.9 & -150 & n.d. & -42.0 & 98.02 & 0.08 & 0.03 & n.d. & n.d. & n.d. & n.d. & 1.82 & 1169 \\
\hline & 3.5 & -79.9 & -162 & n.d. & -39.4 & 97.87 & 0.08 & n.d. & n.d. & n.d. & 0.06 & n.d. & 1.99 & 1241 \\
\hline & 3.7 & -79.1 & -152 & n.d. & -43.0 & 97.14 & 0.10 & 0.05 & n.d. & n.d. & n.d. & n.d. & 2.64 & 1010 \\
\hline & $3.4(\mathrm{HG})$ & -77.3 & -188 & n.d. & -43.2 & 99.84 & 0.04 & 0.002 & 0.003 & n.d. & n.d. & n.d. & 0.11 & 2299 \\
\hline
\end{tabular}




\subsection{Alteration of Hydrocarbon Gas}

Various marine sediments of $\varepsilon c$ values range from 49 to over 100, with values most commonly around 65-75 (Figure 3) [35,48,49]. Our data at AMZ 119 (Amazon fan proper) are consistent with methanogenesis by microbial $\mathrm{CO}_{2}$ reduction in the literature, showing values ranging from 64 to 68 . On the other hand, $\varepsilon c$ values of gases from the headspace from PUC 03, PUCH 01B, AMZ 121 and AMZ 319R range from 20 to 55, which is significantly smaller than that expected from $\mathrm{CO}_{2}$ reduction. In the adjacent continental slope area, the $\varepsilon \mathrm{c}$ values from PUC 03 range 25-35, while for PUCH 01B the range was 20-50. In the Amazon fan area, the AMZ 121, AMZ 319R and PUC 35B range was 37-50, $36-44$ and 28-50, respectively.

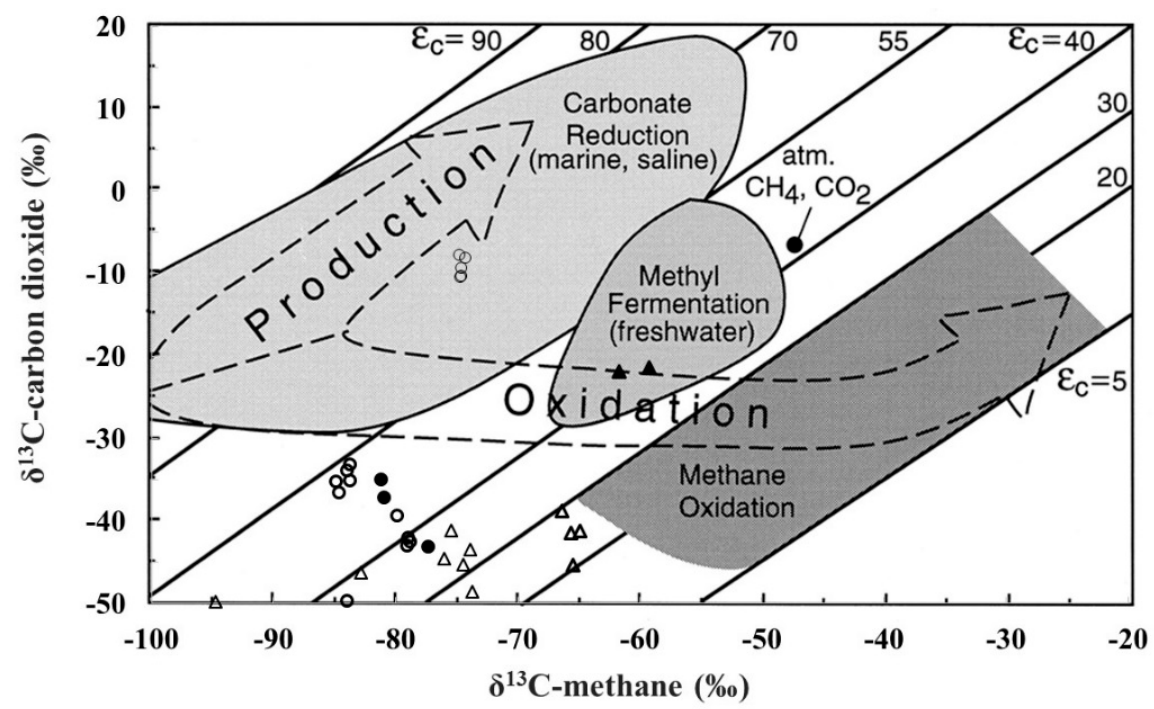

Figure 3. Combination plot of $\delta^{13} \mathrm{C}-\mathrm{CO}_{2}$ and $\delta^{13} \mathrm{C}-\mathrm{CH}_{4}$ with isotope fractionation lines $(\varepsilon \mathrm{c})$. Methanogenesis by carbonate reduction (saline, marine region) has a larger $\mathrm{CO}_{2}-\mathrm{CH}_{4}$ isotope separation than methane consumption. The figure also shows the observed $\mathrm{CO}_{2}-\mathrm{CH}_{4}$ carbon isotope partitioning trajectories resulting from both microbial methane formation and oxidation processes (adapted from Whiticar [35]).

At first glance, our $\varepsilon \mathrm{c}$ results suggest that methane in gas hydrates in the PUC 01B sample originated from methyl fermentation in freshwater or the gas composition contained a fraction of ${ }^{13} \mathrm{C}$ enriched from a thermogenic source. However, this indication is not consistent with the molecular and isotopic data, which clearly document microbial methane generation via $\mathrm{CO}_{2}$ reduction (Figure $2 b$ ).

There are some processes that may affect the molecular and isotopic composition of a gas after its formation/accumulation in a reservoir or during its migration to the surface: (i) mixing of several gas sources, and (ii) anaerobic oxidation of methane $[35,50,51]$. These processes are described below in the context of our samples.

\subsubsection{Mixing of Several Gas Sources}

Gases can be mixed in the reservoir or mixing can happen during migration through the sediments, where microbial gas pools may exist at shallower depths. A detectable thermogenic influence in the gas mix is possibly stronger, at the vicinity of gas conduits like faults, connecting deep gas sources to the surface [52]. The attribution of mixing is due to other secondary post-synthesis processes and the values of carbon isotopes of $\mathrm{CH}_{4}$ alone can be misleading. The recognition of mixing should be based on $\delta^{13} \mathrm{C}_{-} \mathrm{CH}_{4}$ vs. $\mathrm{C} 1 /(\mathrm{C} 2+\mathrm{C} 3)$ plots, as can be seen in the continental slope area plots (Figure $2 \mathrm{~b}$ ).

If we look only at the $\delta^{13} \mathrm{C}-\mathrm{CH}_{4}$ vs. $\mathrm{C} 1 /(\mathrm{C} 2+\mathrm{C} 3)$ plots, mixing of several sources can be partially excluded in the Amazon fan samples, according to the isotopic signatures of methane that show a clear microbial origin. However, in marine sediments, methanogenesis from microbial $\mathrm{CO}_{2}$ reduction 
usually leads to an $\varepsilon$ c range of $49-100 \%$. Furthermore, the carbon fractionation factor $\varepsilon c$, which is the difference between $\delta^{13} \mathrm{C}-\mathrm{CO}_{2}$ and $\delta^{13} \mathrm{C}_{-}-\mathrm{CH}_{4}$, should remain constant upon depletion [35]. However, in this work, this factor varied widely between $28 \%$ and $67 \%$ in samples from the Amazon fan proper, and $20-50 \%$ in the adjacent continental slope area. The values obtained here fell below the normal range $(49-100 \%)$, except for the gas sample PC AMZ 119. Low $\varepsilon \mathrm{C}$ values may be partly explained by the fact that methane is transported by both diffusion as a dissolved phase and advection as gas bubbles, in which the latter is probably an important process owing to the presence of large quantities of gas venting on the water column [21]. The acoustic chimneys in the Amazon fan and adjacent slope area are usually associated with the presence of numerous fractures [53-55], which may act as potential fluid conduits for the upward migration of microbial gas or thermogenic gases [56]. Methane transport in the gas phase forms massive hydrates at the chimney sites in this basin [21].

The predominance of isotopically light methane in sampled sediment cores to depths of $380 \mathrm{mbsf}$, drilled in the Gulf of Mexico in 2005, and the minor amounts of clearly petroleum-related thermogenic gas, and the widespread occurrence of thermogenic gas in the northern Gulf Mexico was surprising. The exact origin of that deeper gas source was uncertain, but Lorenson et al. [57] based their results on the biodegradation of petroleum that originated in more deeply buried sediments. In the present work, we do not have the same interval depth as Lorenson's study; however, in a few meters we found: (1) trace amounts of heavy hydrocarbons in the gas hydrate composition; (2) enrichment of the heavier ${ }^{13} \mathrm{C}$ in methane of sediments with increasing depths; (3) enrichment of ${ }^{13} \mathrm{C}$ in methane comparing gas hydrate in different depths; and, (4) trace amounts of other low-molecular-weight hydrocarbons (propane, propylene and butane) in sediments.

Even with a biogenic origin related to microbial $\mathrm{CO}_{2}$ reduction, it is important to mention that the gas composition of gas hydrate also showed trace amounts of propane and propylene in the deepest depth (3.4 mbsf) in AMZ 319R, which was typically indicative of a thermogenic contribution for the total gas composition. In Figure 4, even without apparent enrichment of gases dissolved in pore water, there was enrichment in ${ }^{13} \mathrm{C}$ in methane in the samples from gas hydrates, in relation to free gas and dissolved gas samples (i.e., $\delta^{13} \mathrm{CH}_{4}$ was $-80.9 \%$ and $-77.3 \%$ in $1.5 \mathrm{mbsf}$ and $3.4 \mathrm{mbsf}$, respectively). Furthermore, the $\delta^{13} \mathrm{CH}_{4}$ values of free and dissolved gases showed enrichment of ${ }^{13} \mathrm{C}$ and there was a possible trend in which heavier carbon isotopes became more prominent with depth. These enrichments (both in gas hydrate as free and dissolved gasses) indicate that there was some possible thermogenic contribution to the mostly biogenic analysed gas mix. Finally, the low concentration of some hydrocarbons such as propane and butane, for example, is possibly due to high microbial degradation $[44,47,58,59]$. Therefore, the ratio $\mathrm{C} 1 /(\mathrm{C} 2+\mathrm{C} 3)$ could be modified to high values and could have masked the thermogenic origin. Figure 4 shows the relationship between the isotopic compositions and depth in sites AMZ 121 and AMZ 319R. 


\section{Amazon Fan}

PUC 35B

AMZ 119
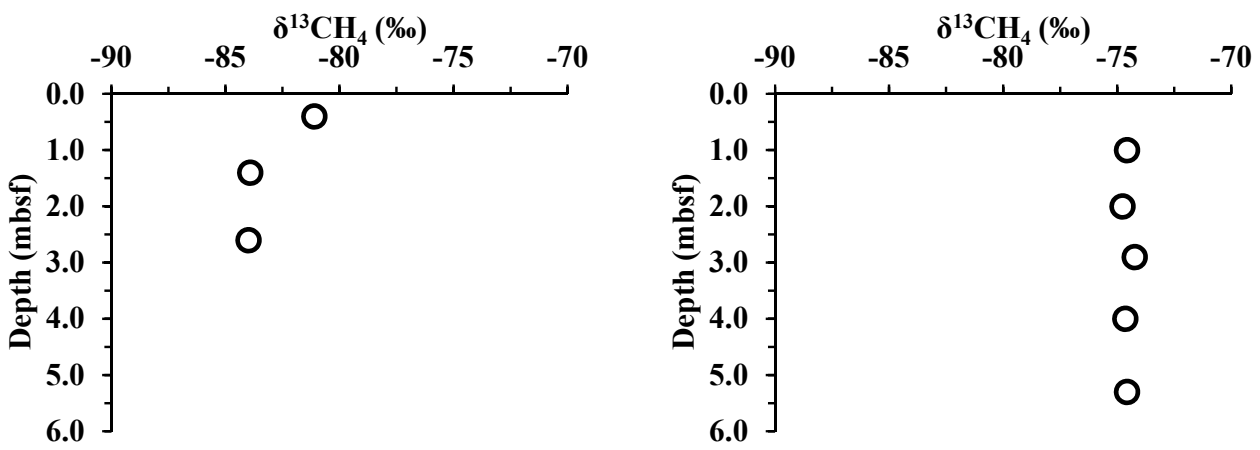

AMZ 121

AMZ 319R
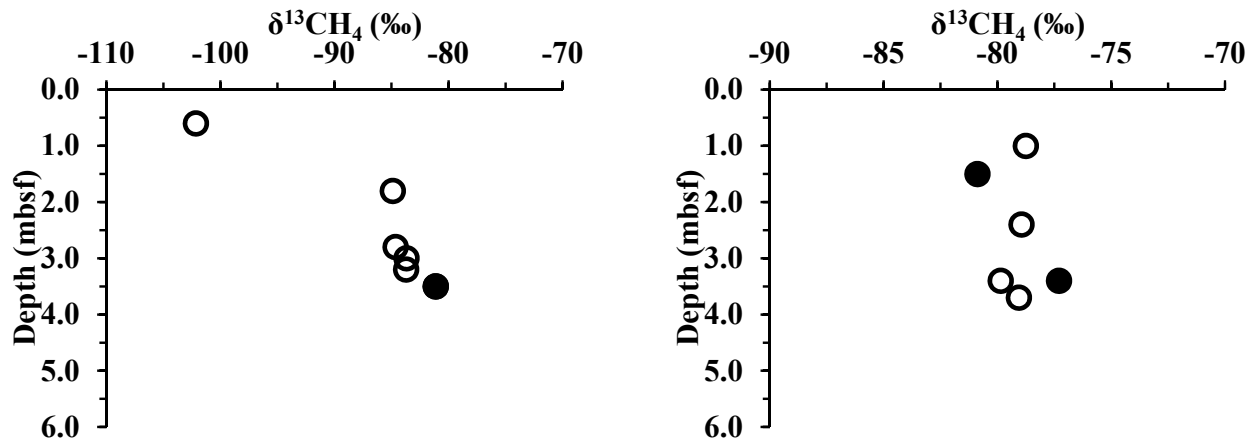

\section{Northwest Continental Slope}

PUC 03

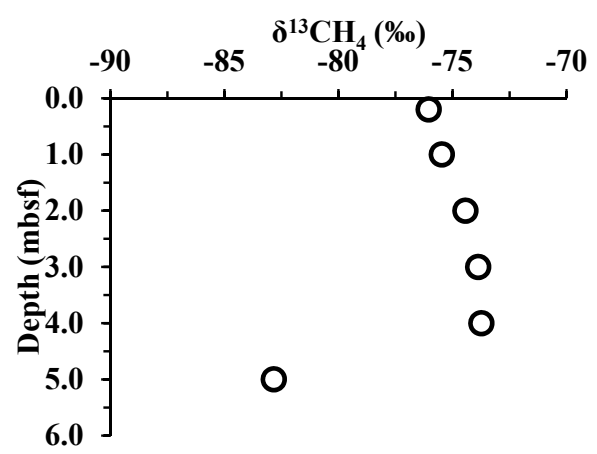

PUCH 01B

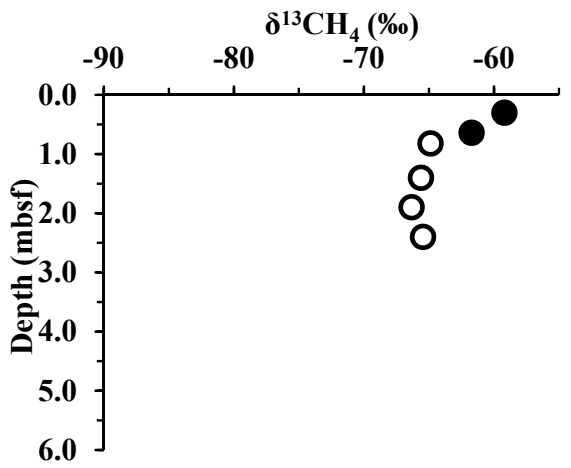

Figure 4. Diagrams showing the changes in the isotopic compositions with depth in sites of Amazon fan and northwest continental slope. Open and solid circles indicate dissolved gases in pore water and hydrate-bound gases, respectively.

Light isotopic values of $\mathrm{CO}_{2}$, similar to the ones found in the Amazon deep-sea fan, were also described by Milkov [60]. Gases with $\mathrm{CO}_{2}$ mostly enriched in ${ }^{12} \mathrm{C}$ have the most significant contribution of primary microbial and/or thermogenic methane and/or may represent the initial $\mathrm{CO}_{2}$ from 
petroleum biodegradation, which had not yet been converted to methane [61] or was generated during biodegradation [62,63]. In gases with $\mathrm{CO}_{2}$ mostly depleted in the lighter isotope ${ }^{12} \mathrm{C}$, a significant portion of $\mathrm{CO}_{2}$ was apparently converted into methane and most $\mathrm{CO}_{2}$ was the residual gas from methanogenesis. Based on this discussion, the $\mathrm{CO}_{2}$ produced during oil and gas biodegradation (without methanogenesis) should have d13C values ranging from $-39 \%$ to $-25 \%$ for oil [ $62-64$ ] and $<-40 \%$ for gas [65] which is generally more negative than the $\delta^{13} \mathrm{C}$ of $\mathrm{CO}_{2}$ liberated from dispersed organic matter during diagenesis.

Therefore, in this work, we suggest that the isotopic composition of the $\mathrm{CO}_{2}$ is from gas oxidation (light hydrocarbons) and not from the methanogenic biodegradation of petroleum hydrocarbons through carbon dioxide reduction. Our $\delta^{13} \mathrm{C}_{\text {of }} \mathrm{CO}_{2}$ low values indicate, therefore, that $\mathrm{CO}_{2}$ is not formed by methanogenic biodegradation of petroleum. The carbon isotope compositions of carbon dioxide reflect its genetic origins. However, as carbon dioxide has higher chemical reactivity and a wide range of potential genetic origins and sinks compared with hydrocarbons, it is usually difficult to determine its specific origin. Some main processes may affect molecular and isotopic composition of gas after its formation/accumulation in a reservoir or during its migration to the surface.

\subsubsection{Anaerobic Oxidation of Methane}

Another process that may affect the molecular and isotopic composition of a gas after its formation/accumulation in a reservoir or during its migration to the surface can be the anaerobic oxidation of methane. A possible explanation is the simplest occurrence of biogeochemical processes, specifically the anaerobic oxidation of methane coupled with carbonate precipitation within the sediment column. The latter process preferentially takes up methane with the lighter carbon isotope [66], therefore producing a ${ }^{12} \mathrm{C}$-enriched $\mathrm{CO}_{2}$ that leads to a decrease of $\varepsilon \mathrm{c}$, as shown in Figure $4[35,67]$. Methane is consumed by microbes at a greater rate than the heavier hydrocarbon gases. This reaction also results in a $\mathrm{CO}_{2}$ pool that is enriched in ${ }^{12} \mathrm{C}$ [35], with reported $\varepsilon \mathrm{c}$ values between 5 and 25 towards the latter stages of $\mathrm{CH}_{4}$ consumption by $\mathrm{AOM}$, which are due to the enrichment of ${ }^{13} \mathrm{C}$ in the residual methane, rather than to an increase in ${ }^{12} \mathrm{CO}_{2}$ from the oxidized methane. The larger pool of $\mathrm{CO}_{2}$ relative to $\mathrm{CH}_{4}$ obscures the oxidation trend of $\varepsilon \mathrm{c}$ values in its initial stage [49]. Hence, AOM could be a potential factor contributing to the small $\varepsilon c$ observed in the studied samples.

Gases with $\mathrm{CO}_{2}$ enriched in ${ }^{12} \mathrm{C}$ make the most significant contribution to primary microbial and/or thermogenic methane and/or may represent the initial $\mathrm{CO}_{2}$ from petroleum biodegradation, which has not yet been converted to methane [61] or was generated during aerobic biodegradation [63]. In gases with $\mathrm{CO}_{2}$ mostly depleted in ${ }^{12} \mathrm{C}$, a significant portion of $\mathrm{CO}_{2}$ was apparently converted into methane and most remaining $\mathrm{CO}_{2}$ was the residual gas from methanogenesis [68]. Because ${ }^{12} \mathrm{C}-{ }^{12} \mathrm{C}$ bonds are easier to break than ${ }^{12} \mathrm{C}-{ }^{13} \mathrm{C}$ bonds, biodegraded residual gases become enriched in ${ }^{13} \mathrm{C}$ isotopes while produced $\mathrm{CO}_{2}$ would be depleted in ${ }^{13} \mathrm{C}$ [44]. These gases are dissolved in biodegraded oils and contain high concentrations of ${ }^{12} \mathrm{C}$-depleted $\mathrm{CO}_{2}$, suggesting significant biodegradation of liquid hydrocarbons but perhaps limited biodegradation of gases [60].

In marine sediments, methanogenesis from microbial $\mathrm{CO}_{2}$ reduction usually leads to an $\varepsilon \mathrm{c}$ range of $49-100 \%$. The values obtained for many samples in this work fell below this range. The most convincing explanation remains the occurrence of biogeochemical processes, more specifically the anaerobic oxidation of methane. This process preferentially takes up methane with the lighter carbon atom [66], therefore producing a ${ }^{12} \mathrm{C}$-enriched $\mathrm{CO}_{2}$, which leads to a decrease of $\varepsilon \mathrm{c}$, as shown in Figure 3 . Ruffine et al. [56] determined the nature and origin of the gases bubbling at the Bay of Biscay. Their data were also plotted outside the appointed fields due to the very light carbon isotopic composition of $\mathrm{CO}_{2}$. They attributed the very light carbon isotopic composition to anaerobic oxidation of methane, coupled with carbonate precipitation within the sedimentary column [56]. Recently, archaeal 16S rRNA gene sequences were recovered that were characteristic of anaerobic methane oxidizers from biodegraded oil reservoirs. This suggested that anaerobic methane oxidation occurred at some point 
during the subsurface degradation process [47]. As was mentioned, the gas biodegradation (without methanogenesis) should have $\mathrm{d} 13 \mathrm{C}$ values $<-40 \%$ for gas [65], which is generally more negative than the $\delta^{13} \mathrm{C}$ of $\mathrm{CO}_{2}$ liberated from dispersed organic matter during diagenesis.

\section{Conclusions}

Understanding the origin and composition of gases (methane, $\mathrm{CO}_{2}$ ) in sediments and gases trapped in gas hydrates can help us to assess natural resources in sedimentary basins and also to better understand the global carbon cycle. Our findings suggest that, in addition to large quantities of methane formed by biogenic processes, the sediments and gas hydrates in the study area contain detectable quantities of gases of thermogenic origin. These gases are stored in the sediments and in gas hydrates, but also venting, and therefore, transferring mass (hydrocarbons of biogenic and thermogenic origins) to the ocean. The molecular and stable isotope compositions of hydrate-bound, free and dissolved gases in sediments from the Amazon fan and adjacent continental slope areas are different. For the Amazon fan there was a dominant microbial origin of methane via carbon dioxide reduction; however, a possible mixture of thermogenic and microbial gases resulted in relatively high methane $\delta^{13} \mathrm{C}$ signatures in one of the sites in the adjacent continental slope. The values obtained for carbon fractionation factor $(\varepsilon c)$ between $\delta^{13} \mathrm{C}_{-} \mathrm{CO}_{2}$ and $\delta^{13} \mathrm{C}-\mathrm{CH}_{4}$ were below the normal range expected for biogenic methane in marine settings. The low values of $\varepsilon \mathrm{c}$ suggested that some processes may have affected the molecular and isotopic composition of gases after their formation/accumulation in a reservoir or during their migration due to: (i) the mixing of several gas sources or (ii) the anaerobic oxidation of methane.

Author Contributions: Conceptualization: L.F.R.; investigation: L.F.R., J.M.K., R.R.O., A.R.V., A.H.A. and J.A.C.; formal analysis: V.H.J.M.d.S., B.L., A.H.A. and L.F.R.; writing—original draft preparation: L.F.R.; writing—review and editing: L.F.R., J.M.K., J.A.C., A.R.V., B.L. and W.D.

Funding: This research received no external funding.

Acknowledgments: The authors thank SeaSeep Ltd. for collaboration in this research and for the permission to publish this paper, and the IHS Global Inc. Educational/Academic Grant Program for the use of the Kingdom Software. J.M.K. thanks the Brazilian National Research Council (CNPq -research grant No. 309915/2015-5), and the Brazilian Coordination for the Improvement of Higher Education Personnel (CAPES—research grant No. 0558/2015) for financial support.

Conflicts of Interest: The authors declare no conflict of interest.

\section{References}

1. Arning, E.T.; van Berk, W.; Vaz dos Santos Neto, E.; Naumann, R.; Schulz, H.M. The quantification of methane formation in Amazon Fan sediments (ODP Leg 155, Site 938) by hydrogeochemical modeling solid-Aqueous solution-Gas interactions. J. S. Am. Earth Sci. 2013, 42, 205-215. [CrossRef]

2. Sun, X.; Sun, C.; Xiang, J.; Jia, J.; Li, P.; Zhang, Z. Acidolysis hydrocarbon characteristics and significance of sediment samples from the ODP drilling legs of gas hydrate. Geosci. Front. 2012, 3, 515-521. [CrossRef]

3. Boswell, R.; Collett, T.S. Current perspectives on gas hydrate resources. Energy Environ. Sci. 2011, 4, 1206-1215. [CrossRef]

4. Chong, Z.R.; Hern, S.; Yang, B.; Babu, P.; Linga, P.; Li, X. Review of natural gas hydrates as an energy resource: Prospects and challenges. Appl. Energy 2016, 162, 1633-1652. [CrossRef]

5. Makogon, Y.F. Natural gas hydrates-A promising source of energy. J. Nat. Gas Sci. Eng. 2010, 2, 49-59. [CrossRef]

6. Archer, D. Methane hydrate stability and anthropogenic climate change. Biogeosci. Discuss. 2007, 4, 993-1057. [CrossRef]

7. Archer, D.; Buffett, B.; Brovkin, V. Ocean methane hydrates as a slow tipping point in the global carbon cycle. Proc. Natl. Acad. Sci. USA 2009, 106, 20596-20601. [CrossRef]

8. Sultan, N.; Cochonat, P.; Foucher, J.P.; Mienert, J. Effect of gas hydrates melting on seafloor slope instability. Mar. Geol. 2004, 213, 379-401. [CrossRef]

9. Reeburgh, W. Oceanic methane biogeochemistry. Am. Chem. Soc. 2007, 107, 486-513. [CrossRef] 
10. Hunter, S.J.; Goldobin, D.S.; Haywood, A.M.; Ridgwell, A.; Rees, J.G. Sensitivity of the global submarine hydrate inventory to scenarios of future climate change. Earth Planet. Sci. Lett. 2013, 367, 105e115. [CrossRef]

11. Ribeiro, I.O.; de Souza, R.A.F.; Andreoli, R.V.; Kayano, M.T.; Costa, P. dos S. Spatiotemporal variability of methane over the Amazon from satellite observations. Adv. Atmos. Sci. 2016, 33, 852-864. [CrossRef]

12. Dickens, G.R.; Castillo, M.M.; Walker, J.C.G. A blast of gas in the latest Paleo-cene: Simulating first-order effects of massive dissociation of oceanic methane hydrate. Geology 1997, 25, 259e262. [CrossRef]

13. Miller, D.J.; Ketzer, J.M.; Viana, A.R.; Kowsmann, R.O.; Freire, A.F.M.; Oreiro, S.G.; Augustin, A.H.; Lourega, R.V.; Rodrigues, L.F.; Heemann, R.; et al. Natural gas hydrates in the Rio Grande Cone (Brazil): A new province in the western South Atlantic. Mar. Pet. Geol. 2015, 67, 187-196. [CrossRef]

14. Giongo, A.; Haag, T.; Simão, T.L.L.; Medina-Silva, R.; Utz, L.R.P.; Bogo, M.R.; Bonatto, S.L.; Zamberlan, P.M.; Augustin, A.H.; Lourega, R.V.; et al. Discovery of a chemosynthesis-based community in the western South Atlantic Ocean. Deep Res. Part I Oceanogr. Res. Pap. 2016, 112, 45-56. [CrossRef]

15. Medina-Silva, R.; Oliveira, R.R.; Trindade, F.J.; Borges, L.G.A.; Lopes, S.T.; Augustin, A.H.; Valdez, F.P.; Constant, M.J.; Simundi, C.L.; Eizirik, E.; et al. Microbiota associated with tubes of Escarpia sp. from cold seeps in the southwestern Atlantic Ocean constitutes a community distinct from that of surrounding marine sediment and water. Antonie Van Leeuwenhoek 2018, 111, 533-550. [CrossRef] [PubMed]

16. Rodrigues, L.F.; Ketzer, J.M.; Lourega, R.V.; Augustin, A.H.; Sbrissa, G.; Miller, D.; Heemann, R.; Viana, A.; Freire, A.F.M.; Morad, S. The influence of methane fluxes on the sulfate/methane interface in sediments from the Rio Grande Cone Gas Hydrate Province, Southern Brazil. Braz. J. Geol. 2017, 47, 369-381. [CrossRef]

17. Rodrigues, L.F.; Macario, K.D.; Anjos, R.M.; Ketzer, J.M.M.; Augustin, A.H.; Moreira, V.N.; dos Santos, V.H.J.M.; Muniz, M.C.; Cardoso, R.P.; Viana, A.R.; et al. Origin of organic matter in hydrate-bearing sediments of the Rio Grande Cone: Evidence from TOC, TN, $\delta 13 \mathrm{C}$ and 14C isotopes. In Proceedings of the 9th International Conference on Gas Hydrates, Denver, CO, USA, 25-30 June 2017.

18. Flood, R.D.; Piper, D.J.W.; Klaus, A.; Burns, S.J.; Busch, W.H.; Cisowski, S.M.; Cramp, A.; Damuth, J.E.; Goñi, M.A.; Haberle, S.G.; et al. Proceedings of the Ocean Drilling Program, Scientific Results; Texas A \& M University, Ocean Drilling Program: College Station, TX, USA, 1995; Volume 155, p. 695. ISSN 0884-5891.

19. Hinrichs, K.-U.; Rullkotter, J. Terrigenous and marine lipids in Amazon Fan sediments: Implications for sedimentological reconstructions. Proc. Ocean Drill. Progr. Sci. Res. 1997, 155, 539-553. [CrossRef]

20. Pirmez, C.; Flood, R.D.; Baptiste, J.; Yin, H.; Manley, P.L. Clay content, porosity and velocity of Amazon Fan sediments determined from ODP Leg 155 cores and wireline logs. Geophys. Res. Lett. 1997, 24, 317-320. [CrossRef]

21. Ketzer, J.M.; Augustin, A.; Rodrigues, L.F.; Oliveira, R.; Praeg, D.; Pivel, M.A.P.; Reis, A.T.; Silva, C.; Leonel, B. Gas hydrates and gas seepage in the Amazon deep-sea fan. Geo-Mar. Lett. 2018, 38, 1-10. [CrossRef]

22. Figueiredo, A.G.; Nittrouer, C.A.; de Alencar Costa, E. Gas-charged sediments in the Amazon submarine delta. Geo-Mar. Lett. 1996, 16, 31-35. [CrossRef]

23. Maslin, M.; Vilela, C.; Mikkelsen, N.; Grootes, P. Causes of catastrophic sediment failures of the Amazon Fan. Quat. Sci. Rev. 2005, 24, 2180-2193. [CrossRef]

24. Maslin, M.; Fleet, A.J. Equatorial western Atlantic Ocean circulation changes linked to the Heinrich events: deep-sea sediment evidence from the Amazon Fan. Geol. Evol. Ocean Basins Res. Ocean Drill. Progr. 1998, 131, 111-127. [CrossRef]

25. Reis, A.T.; Perovano, R.; Silva, C.G.; Vendeville, B.C.; Araujo, E.; Gorini, C.; Oliveira, V. Two-scale gravitational collapse in the Amazon Fan: A coupled system of gravity tectonics and mass-transport processes. J. Geol. Soc. Lond. 2010, 167, 593-604. [CrossRef]

26. Danmuth, J.E.; Kumar, N. Amazon Cone: Morphology, sedimentats, and growth pattern. Geol. Soc. Am. Bull. 1975, 86, 863-878. [CrossRef]

27. Manley, P.L.; Flood, R.D. Cyclic sediment deposition within Amazon deep-sea fan. Am. Assoc. Pet. Geol. Bull. 1988, 72, 912-925. [CrossRef]

28. Tanaka, M.D.; Silva, C.G.; Clennell, M.B. Gas Hydrates on the Amazon Submarine Fan, Foz do Amazonas Basin, Brazil. In Proceedings of the AAPG Annual Convention, Salt Lake, UT, USA, 11-14 May 2003; pp. 3-5.

29. Carvalho, G.C.R.d.; Gomes, C.J.S.; Martins Neto, M.A. O Cone do Amazonas, bacia da Foz do Amazonas: Uma nova discussão. Rem Revista Escola de Minas 2011, 64, 429-437. [CrossRef]

30. Richey, J.E.; Brock, J.T.; Naiman, R.J.; Wissmar, R.C.; Stallard, R.F. Organic Carbon: Oxidation and Transport in the Amazon River. Science 1980, 207, 1348-1351. [CrossRef] 
31. IsoTech Labs Inc. Procedure for Taking Cuttings Samples in IsoJars ${ }^{\circledR}$. Weatherford Laboratories. 2018. Available online: http:/ / www.isotechlabs.com/customersupport/samplingprocedures/IsoJarSM.pdf (accessed on 14 June 2018).

32. Oung, J.N.; Lee, C.Y.; Lee, C.S.; Kuo, C.L. Geochemical Study on Hydrocarbon Gases in Seafloor Sediments, Southwestern Offshore Taiwan-Implications in the Potential Occurrence of Gas Hydrates. Terr. Atmos. Ocean. Sci. 2006, 17, 921-931. [CrossRef]

33. Rodrigues, L.F.; Goudinho, F.S.; Laroque, D.O.; Lourega, R.V.; Heemann, R.; Ketzer, J.M.M. An Alternative Gas Chromatography Setting for Geochemical Analysis. J. Chem. Eng. Process Technol. 2014, 5, 208. [CrossRef]

34. Bernard, B.B.; Brooks, J.M.; Sackett, W.M. Natural gas seepage in the Gulf of Mexico. Earth Planet. Sci. Lett. 1976, 31, 48-54. [CrossRef]

35. Whiticar, M.J. Carbon and hydrogen isotope systematics of bacterial formation and oxidation of methane. Chem. Geol. 1999, 161, 291-314. [CrossRef]

36. Paull, C.K.; Lorenson, T.D.; Borowski, W.S.; Ussler, W., III; Olsen, K.; Rodriguez, N.M. Isotopic Composition of $\mathrm{CH} 4, \mathrm{CO} 2$ Species, and Sedimentary Organic Matter Within Samples From the Blake Ridge: Gas Source Implications. Proc. Ocean Drill. Program. Sci. Results 2000, 164, 67-78. [CrossRef]

37. Pape, T.; Bahr, A.; Rethemeyer, J.; Kessler, J.D.; Sahling, H.; Hinrichs, K.U.; Klapp, S.A.; Reeburgh, W.S.; Bohrmann, G. Molecular and isotopic partitioning of low-molecular-weight hydrocarbons during migration and gas hydrate precipitation in deposits of a high-flux seepage site. Chem. Geol. 2010, 269, 350-363. [CrossRef]

38. Römer, M.; Sahling, H.; Pape, T.; Bahr, A.; Feseker, T.; Wintersteller, P.; Bohrmann, G. Geological control and magnitude of methane ebullition from a high-flux seep area in the Black Sea-The Kerch seep area. Mar. Geol. 2012, 319, 57-74. [CrossRef]

39. Milkov, A.V. Molecular and stable isotope compositions of natural gas hydrates: A revised global dataset and basic interpretations in the context of geological settings. Org. Geochem. 2005, 36, 681-702. [CrossRef]

40. Taylor, S.W.; Sherwood Lollar, B.; Wassenaar, I. Bacteriogenic Ethane in Near-Surface Aquifers: Implications for Leaking Hydrocarbon Well Bores. Environ. Sci. Technol. 2000, 34, 4727-4732. [CrossRef]

41. Kvenvolden, K.A. A review of the geochemistry of methane in gas hydrate. Org. Geochem. 1995, 23, 997-1008. [CrossRef]

42. Pallasser, R.J. Recognizing biodegradation in gas/oil accumulations through the d13C compositions of gas components. Org. Geochem. 2000, 31, 1363-1373. [CrossRef]

43. Waseda, A.; Iwano, H. Characterization of natural gases in Japan based on molecular and carbon isotope compositions. Geofluids 2008, 8, 286-292. [CrossRef]

44. James, A.T.; Burns, B.J. Microbial alteration of subsurface natural gas accumulations. Am. Assoc. Pet. Geol. Bull. 1984, 68, 957-960.

45. Horstad, I.; Larter, S.R. Petroleum migration, alteration, and remigration within Troll Field, Norwegian North Sea. Bull. Am. Assoc. Petrol. Geol. 1997, 81, 222-248. [CrossRef]

46. Boreham, C.J.; Hope, J.M.; Hartung-Kagi, B. Understanding source, distribution and preservation of Australian natural gas: A geochemical perspective. Aust. Pet. Prod. Explor. Assoc. J. 2001, 41, 523-547. [CrossRef]

47. Head, I.M.; Jones, D.M.; Larter, S.R. Biological activity in the deep subsurface and the origin of heavy oil. Nature 2003, 426, 344-352. [CrossRef] [PubMed]

48. Pohlman, J.W.; Bauer, J.E.; Canuel, E.A.; Grabowski, K.S.; Knies, D.L.; Mitchell, C.S.; Whiticar, M.J.; Coffin, R.B. Methane sources in gas hydrate-bearing cold seeps: Evidence from radiocarbon and stable isotopes. Mar. Chem. 2009, 115, 102-109. [CrossRef]

49. Whiticar, M.J.; Faber, E.; Schoell, M. Biogenic methane formation in marine and freshwater environments: $\mathrm{CO} 2$ reduction vs acetate fermentation-Isotope evidence. Geochim. Cosmochim. Acta 1986, 50, 693-709. [CrossRef]

50. Choi, J.; Kim, J.H.; Torres, M.E.; Hong, W.L.; Lee, J.W.; Yi, B.Y.; Bahk, J.J.; Lee, K.E. Gas origin and migration in the Ulleung Basin, East Sea: Results from the Second Ulleung Basin Gas Hydrate Drilling Expedition (UBGH2). Mar. Pet. Geol. 2013, 47, 113-124. [CrossRef]

51. Prinzhofer, A.; Pernaton, É. Isotopically light methane in natural gas: Bacterial imprint or diffusive fractionation? Chem. Geol. 1997, 142, 193-200. [CrossRef] 
52. Wilson, R.M.; Macelloni, L.; Simonetti, A.; Lapham, L.; Lutken, C.; Sleeper, K.; D’Emidio, M.; Pizzi, M.; Knapp, J.; Chanton, J. Subsurface methane sources and migration pathways within a gas hydrate mound system, Gulf of Mexico. Geochem. Geophys. Geosyst. 2014, 15, 89-107. [CrossRef]

53. Bahk, J.J.; Kim, J.H.; Kong, G.S.; Park, Y.; Lee, H.; Park, Y.; Park, K.P. Occurrence of near-seafloor gas hydrates and associated cold vents in the Ulleung Basin, East Sea. Geosci. J. 2009, 13, 371-385. [CrossRef]

54. Haacke, R.R.; Hyndman, R.D.; Park, K.P.; Yoo, D.G.; Stoian, I.; Schmidt, U. Migration and venting of deep gases into the ocean through hydrate-choked chimneys offshore Korea. Geology 2009, 37, 531-534. [CrossRef]

55. Horozal, S.; Lee, G.H.; Yi, B.Y.; Yoo, D.G.; Park, K.P.; Lee, H.Y.; Kim, W.; Kim, H.J.; Lee, K. Seismic indicators of gas hydrate and associated gas in the Ulleung Basin, East Sea (Japan Sea) and implications of heat flows derived from depths of the bottom-simulating reflector. Mar. Geol. 2009, 258, 126-138. [CrossRef]

56. Ruffine, L.; Donval, J.P.; Croguennec, C.; Bignon, L.; Birot, D.; Battani, A.; Bayon, G.; Caprais, J.C.; Lantéri, N.; Levaché, D.; et al. Gas seepage along the edge of the Aquitaine shelf (France): Origin and local fluxes. Geofluids 2017, 2017. [CrossRef]

57. Lorenson, T.D.; Claypool, G.E.; Dougherty, J.A. Natural gas geochemistry of sediments drilled on the 2005 Gulf of Mexico JIP cruise. Mar. Pet. Geol. 2008, 25, 873-883. [CrossRef]

58. Horstad, I.; Larter, S.R.; Mills, N. A quantitative model of biological petroleum degradation within the Brent Group reservoir in the Gullfaks Field, Norwegian North Sea. Org. Geochem. 1992, 19, 107-117. [CrossRef]

59. Larter, S.; di Primio, R. Effects of biodegradation on oil and gas field PVT properties and the origin of oil rimmed gas accumulations. Org. Geochem. 2005, 36, 299-310. [CrossRef]

60. Milkov, A.V. Worldwide distribution and significance of secondary microbial methane formed during petroleum biodegradation in conventional reservoirs. Org. Geochem. 2011, 42, 184-207. [CrossRef]

61. Feisthauer, S.; Siegert, M.; Seidel, M.; Richnow, H.H.; Zengler, K.; Gründger, F.; Krüger, M. Isotopic fingerprinting of methane and $\mathrm{CO} 2$ formation from aliphatic and aromatic hydrocarbons. Org. Geochem. 2010, 41, 482-490. [CrossRef]

62. Aggarwal, P.K.; Fuller, M.E.; Gurgas, M.M.; Manning, J.F.; Dillon, M.A. Use of stable oxygen and carbon isotope analyses for monitoring the pathways and rates of intrinsic and enhanced in situ biodegradation. Environ. Sci. Technol. 1997, 31, 590-596. [CrossRef]

63. Zyakun, A.M.; Kosheleva, I.A.; Zakharchenko, V.N.; Kudryavtseva, A.I.; Peshenko, V.A.; Filonov, A.E.; Boronin, A.M. The use of the $[13 \mathrm{C}] /[12 \mathrm{C}]$ ratio for the assay of the microbial oxidation of hydrocarbons. Microbiology 2003, 72, 592-596. [CrossRef]

64. Jones, D.M.; Head, I.M.; Gray, N.D.; Adams, J.J.; Rowan, A.K.; Aitken, C.M.; Bennett, B.; Huang, H.; Brown, A.; Bowler, B.F.J.; et al. Crude-oil biodegradation via methanogenesis in subsurface petroleum reservoirs. Nature 2008, 451, 176-180. [CrossRef] [PubMed]

65. Clayton, C.J.; Hay, S.J.; Baylis, S.A.; Dipper, B. Alteration of natural gas during leakage from a North Sea salt diapir field. Mar. Geol. 1997, 137, 69-80. [CrossRef]

66. Yoshinaga, M.Y.; Holler, T.; Goldhammer, T.; Wegener, G.; Pohlman, J.W.; Brunner, B.; Kuypers, M.M.M.; Hinrichs, K.U.; Elvert, M. Carbon isotope equilibration during sulphate-limited anaerobic oxidation of methane. Nat. Geosci. 2014, 7, 190-194. [CrossRef]

67. Boetius, A.; Ravenschlag, K.; Schubert, C.J.; Rickert, D.; Widdel, F.; Gieseke, A.; Amann, R.; Jørgensen, B.B.; Witte, U.; Pfannkuche, O. A marine microbial consortium apparently mediating anaerobic oxidation of methane. Nature 2000, 407, 623-626. [CrossRef] [PubMed]

68. Jeffrey, A.W.A.; Alimi, H.M.; Jenden, P.D. Geochemistry of Los Angeles Basin oil and gas systems. Act. Margin Basins Aapg Mem. 1991, 52, 197-219.

(C) 2019 by the authors. Licensee MDPI, Basel, Switzerland. This article is an open access article distributed under the terms and conditions of the Creative Commons Attribution (CC BY) license (http://creativecommons.org/licenses/by/4.0/). 